\title{
Paradox for Community College: Education in the '80s
}

\author{
RICHARD L. ALFRED
}

As Community Colleges move toward the '90s, a combination of factors will coalesce to reshape the institutional mission, programs, academic policies, and the context for governance. These factors will be: 1) increasing pressure from external agencies to justify the cost-benefits of academic programs and services to a broad, but potentially diminishing, pool of users and funding sources and 2) growing inability of faculty and staff to respond to pressures for change due to calcification of the decision process in an aging and complex organization. To the experienced community college observer, it is clear that two-year colleges are rapidly approaching a watershed. How will it be possible for our colleges to offer a broad-range of programs and services to multiple clienteles at low cost when public policy is beginning to favor other educational providers in resource allocation decisions, when competition is intensifying for students and resources, when boards of trustees and administrators are becoming enmeshed in a network of agency regulations, and when legislative support is on the wane because community college education is no longer perceived as an enterprise capable of yielding significant political gains to elected officials?

\section{Changing External Conditions and Organizational Characteristics}

This brief concept paper will identify major issues facing community college education in the remainder of the decade. Based on the premise that community colleges are adaptive organizations, incongruence between emerging external conditions and organizational characteristics could result in a paradox which alters the mission and structure of the college. Changing conditions in the external environment are the following:

- Increasing velocity of change in economic, demographic and technical conditions.

- Changing public policy emphases for community college education

-focus on "success" and "access" in legislation and state aid formulas

-emerging emphasis on $\mathrm{K}-12$ education

-emphasis on university research for technological and economic development

- burgeoning committment of public funds to human services 
- Increasing dependence on the state as a revenue source and resulting competition with human service organizations for financial resources.

- Differentiation of economic conditions for community college education on a state-by-state basis and resulting dissolution of the national community college movement.

- Centralization of decision making in state agencies and "standardization" of community college education in finance formulas, capital budget requests, and higher education legislation.

- Increasing pressure on community colleges from state agencies to compact the institutional mission into unduplicated dimensions (mission sectoring).

- Growing national and regional concern for documentation of quality in academic programs and services.

- "Plateau" in institutional relationships with funding sources as "maintenance issues" (faculty salaries, equipment, facilities repairs and cost inflation) take precedence over "development issues."

(new programs, mission restructuring, and innovative services in response to emerging needs) in institional budget requests.

Community colleges, by virtue of evolving changes in the structure and functions of internal management, are not equipped to respond fully to these changing conditions. A cursory review of changes in the organizational structure occurring since 1970 points to problems of specialization, rigidity, and polarization in staff relationships which constrain effective responses to change. Consider for example, the following problems in the internal organization of community colleges today:

- Ambiguity in requirements for the associate degree culminating in expressed concerns about the quality and value of the associate degree.

- Aging programs, equipment, and staff requiring incremental resources for renewal-resources which states and local tax districts cannot provide in quantities sufficient to offset multiple years of underfunding.

- Changing composition of boards of trustees manifested in rising levels of inexperience in understanding and solving problems endemic to complex organizations.

- Elongation of the decision process as on out-growth of shared governance with a resulting increase in the time necessary to respond to changing conditions.

- "Dualism" in management with faculty assuming de facto control over curriculum decisions and administrators over non-academic decisions; polarities exist among parties in the decision process.

- Loss of faculty as full-time partners in the educational enterprise culminating in dissolution of the academic department as a unit for strategic management; faculty are not organized to participate extensively in academic planning and budget decisions nor are they organized to infuse quality into academic advisement and evaluation.

- Specialization in adminstrative functions serving to curtail opportunities for leadership development among faculty and staff.

- Inadequacy in the organization for institutional research serving to impede the progress of community colleges in competition with postsecondary education providers for scarce resources. 


\section{Paradox in Community College Education}

These organizational problems lead to a paradox in community college education. While faculty and administrators have worked hard to perpetuate an image of the community college as a "development organization" - an organization unparalleled in its capacity to respond to a diversity of needs-the college has, in fact, became a "maintenance organization." The emphasis is on perpetuation of a comprehensive mission irrespective of changing conditions. "Institutional uniqueness" in the form of low student costs, open access, comprehensive program/service mix, and quick response to emerging needs has become a dimension of the past. Non-unionized private colleges and proprietary institutions with simplistic organizational structures can respond quickly to emerging needs. They can also recruit students through readily available financial aid. Public four-year colleges can effectively compete with two-year colleges for enrollment through sophisticated technologies. K-12 school districts can offer alternative, low cost learning paths for adult students through incremental resources available via state agencies. The community college-without a major effort to identify new forms of uniqueness and alternative sources of financial support-could become a "redundant" organization in American postsecondary education by the close of the decade.

Steps can be taken to resolve this paradox. A new conceptualization of uniqueness can be developed with the community college positioned as the key provider of specified postsecondary programs and services through carefully defined linkages with public- and private-sector organizations in a delimited service region. Ten strategies can be implemented to achieve this concept of uniqueness:

- Special efforts should be undertaken to maintain a policy of low student cost. A greater share of the responsibility for institutional support should be borne by the local tax district. College leaders should identify innovative methods for improvement of local support beyond those implicit in "traditional" finance strategies.

- Public- and private-sector agencies in the local tax district should become the primary target of attention of faculty and administrators in the design of academic programs and services. Linkages should be forged between academic programs and business and industry to support technical education, student services and community-based human service organizations to support student development, continuing education programs and civic groups to support adult education, and academic staff and K-12 administrators and counselors to support student and program articulation.

- The comprehensive mission of the community college should be limited in scope to educational activities and senvices required for satisfaction of identified needs in the immediate service region. A reasonable exception to this policy would be special purpose programs conducted with the approval and support of state agencies such as retraining of displaced workers, youth offenders, and technology adjustment programs. The local tax district and the state should provide formal approval of the institutional mission in contrast to the mission(s) pursued by other education providers.

- Revenue sources for community college education should be diversified among public- and private-sector organizations in direct relationship to the quantity and quality of benefits rendered to these organizations through college programs and services.

- Requirements for the associate degree should be clarified and strengthened in 
accord with specific credentials required by local organizations (business and industry, human service organizations, four-year colleges and universities, and government agencies) which "receive" community college graduates (and nongraduates). Support for college programs and services is only as good as the perceptions of quality held by individuals, groups and organizations in the local tax district.

- Methods should be identified to "shorten" the decision process. Elongation of the decision process due to excessive requirements for consultation with faculty groups, trustees, and multiple layers of administration may be counter-productive for institutional development in a period of rapid technological change.

- Improvements should be made in the organization for institutional research. The capacity to demonstrate "uniqueness" is directly related to the ability of the institution to report data about student outcomes, social and economic impacts, and the cost-benefits of educational programs and services for specific constituencies. In the absence of such data, "perceptual" or subjective arguments can be made for uniqueness-arguments that can be made by any unit of postsecondary education thereby rendering inadequate the concept of "uniqueness" in budgetary decisions.

- New strategies for marketing college programs and services should be developed with a focus on research data gathered about student outcomes, social and economic impacts, and cost-benefits. Information about outcomes is a powerful tool in marketing when compared to routine information about institutional intentions, course offerings, and academic services.

- Agressive strategies for resource reallocation should be forged in academic programs as a method to produce discretionary income for program development. Administrators who allow weak and ineffective programs to consume vital resources, weaken the entire fabric of the organization and constrain future arguments for uniqueness.

- Imaginative programs for leadership development should be implemented based on a working partnership between community colleges and university graduate programs. Future leaders will require conceptual skills to design a "vision" for the institution and "concepts of uniqueness" for academic programs and services. Experience is an effective teacher, but conceptual understanding of organizational dynamics and social change processes is essential if chief executive officers are to "lead" rather than to "manage" in the decade ahead.

\section{Vision For The Future}

The future of community colleges in a period largely characterized by increasing velocity in the change process depends largely on the attitudes of those in positions of leadership. Loose, soft, and defensive approaches to leadership will have more impact on institutional performance in the next five to ten years than any loss of resources or change in public policy. Because community colleges are no longer in a period of growth does not mean that they should be satisfied with maintenance of existing programs, protection of existing resources, or sustenance of the institutional mission in its current form. Community colleges must be very careful not the direct the full energies of staff to protection of "what they have been." Under the guidance and prodding of leaders, they must reevaluate their mission and educational delivery systems in relationship to those of competitors and systematically carve a new vision 
of the future.

Richard L. Alfred is Associate Professor of Higher Education and Director of the Community College Program, University of Michigan, Ann Arbor, Michigan. 